Discussion Paper No. 05-51

International Capital Mobility and

Current Account Targeting in

Central and Eastern European Countries

Matthias Köhler

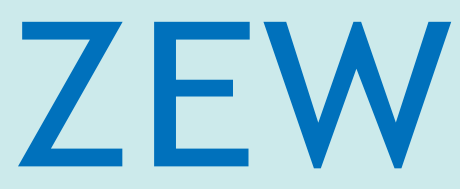

Zentrum für Europäische Wirtschaftsforschung $\mathrm{GmbH}$

Centre for European

Economic Research 


\title{
Discussion Paper No. 05-51 \\ International Capital Mobility and \\ Current Account Targeting in Central and Eastern European Countries
}

\author{
Matthias Köhler
}

Download this ZEW Discussion Paper from our ftp server:

ftp://ftp.zew.de/pub/zew-docs/dp/dp0551.pdf

Die Discussion Papers dienen einer möglichst schnellen Verbreitung von neueren Forschungsarbeiten des ZEW. Die Beiträge liegen in alleiniger Verantwortung der Autoren und stellen nicht notwendigerweise die Meinung des ZEW dar.

Discussion Papers are intended to make results of ZEW research promptly available to other economists in order to encourage discussion and suggestions for revisions. The authors are solely responsible for the contents which do not necessarily represent the opinion of the ZEW. 


\section{Non-Technical Summary}

In May 2004, the Czech Republic, Hungary, Poland, the Slovak Republic and Slovenia (hereafter CEEC-5) joined the European Union (EU). Precondition for the accession was that the countries had met the political and economic criteria and adopted all policies and rules of the EU and to ensure their effective enforcement through appropriate administrative structures. Among these rules some require to remove all barriers that restrict the transfer of capital and services, since only the free flow of capital and services within the community makes it possible to take full advantage of the single market. Furthermore, the harmonization of financial market regulations has positive effects on monetary policy in an enlarged European Monetary Union (EMU), since different financial structures and levels of financial integration impede an efficient monetary policy by the European Central Bank (ECB). This not only endangers price level stability but also economic growth, since monetary impulses might have asymmetric effects on the economy in central and eastern European countries due to different structures and degrees of financial market integration.

To measure this degree of integration the Feldstein-Horioka approach is used that analyzes the degree of financial integration in the CEEC-5 according to the correlation between saving and investment rates. To compare the degree of integration with that of the EMU eleven member countries are included into the regression. Since the results of the Feldstein-Horioka approach are sensitive to current account targeting policies of the government, we included the fiscal budget as additional variable into the regression to control for these kind of policies. We finally analyse the development of the current account of the CEEC-5 in greater detail to find out if the governments in these countries targeted the current account during the period in transformation.

According to our analysis the degree of international capital mobility in the CEEC-5 has reached and even exceeded the degree of capital mobility in the euro zone. This development might be explained with the liberalization of capital flows towards the European and the world capital market during the transition period, while the EMU countries seem to have more concentrated on the removal of barriers within the euro area than toward the world capital market. These results are robust to current account targeting policies. The analysis of the current account furthermore reveals that the countries which faced current account crisis during the transition period used their budget to balance the current account in the years after the crises. The study hence indicates that the accession to the EMU will likely not lead to asymmetric monetary policy impulses according to the Feldstein-Horioka criterion. 


\title{
International Capital Mobility and Current Account Targeting in Central and Eastern European Countries
}

\author{
Matthias Köhler
}

Centre for European Economic Research (ZEW)

June 2005

\begin{abstract}
The paper examines the degree of financial integration in five central and eastern European economies on the basis of saving-investment correlations. A comparison with eleven member states of the European monetary union shows that the countries under review have already reached a higher degree of integration in quantitative terms. Since this approach is sensitive to current account targeting policies, the paper uses econometric techniques to control for these kinds of policies revealing that the central and eastern European countries that suffered from current account crises in the past used policies to balance the current account.
\end{abstract}

Acknowledgement: The author would like to thank Michael Schröder, Andreas Schrimpf and Thomas Pfahler for helpful comments and criticism.

L 7, 1

P.O. Box 103443

68034 Mannheim

Germany
Phone.: $\quad+496211235148$

Fax: $\quad+496211235223$

E-mail: koehler@zew.de 


\section{Introduction}

In May 2004, the Czech Republic, Hungary, Poland, the Slovak Republic and Slovenia (hereafter CEEC-5) joined the European Union (EU). Precondition for the accession was that the countries had met the political and economic criteria and adopted all policies and rules of the EU and to ensure their effective enforcement through appropriate administrative structures. Among these rules some require to remove all barriers that restrict the transfer of capital and services, since only the free flow of capital and services within the community makes it possible to take full advantage of the single market. Furthermore, the harmonization of financial market regulations has positive effects on monetary policy in an enlarged European Monetary Union (EMU), since different financial structures and levels of financial integration impede an efficient monetary policy by the European Central Bank (ECB). This not only endangers price level stability but also economic growth, since monetary impulses might have asymmetric effects on the economy in central and eastern European countries due to different structures and degrees of financial market integration.

The motivation of this study is to measure this degree of integration. The remainder of this paper is organized as follows. In part II, we will present different measures of financial market integration, before we will use one of these indicators in part III to measure the degree of capital mobility econometrically. Since current account policies affect the degree of financial market integration, we will analyse the extent to which these policies were used in the CEEC-5 and to what extent they have influenced the degree of international capital mobility in part IV. Part V concludes.

\section{Measuring Financial Market Integration}

Financial market integration implies that all frictions have been removed that discriminate between economic agents in their access to and the investment of capital on the basis of their location (ECB, 2003, p. 54). Based on this definition of integration three concepts can be distinguished to measure the degree of financial market integration.

Quantity-based indicators measure the degree of financial integration according to the volume of international transactions. Since these indicators only measure the degree of internationalization and not the degree of integration of financial markets, indicators have to be used that analyse the efficiency of the financial sector, which depends upon the level of competition in financial markets. Such indicators base upon the law of one price and are called price indicators. According to these indicators, financial markets are perfectly integrated into the world capital market if nominal and real interest rate parity holds. ${ }^{1} \mathrm{~A}$ further indicator that combines

1 Herrmann and Jochem (2003a and 2003b) recorded deviations from covered interest rate parity and speculative efficiency in the Czech Republic, Hungary, Poland and the Slovak Republic. 
quantity-based indicators and price indicators is the Feldstein-Horioka test which is named after Feldstein and Horioka (1980) who used it to measure the degree of international capital mobility of 16 OECD countries. The idea behind this indicator is that in closed economies domestic investment is limited by domestic savings. Saving and investment rates are hence expected to be highly correlated if financial markets are separated from the world capital market. In order to test their hypothesis, Feldstein and Horioka regressed the domestic saving rate on the domestic investment rate for a cross-section of 16 OECD countries averaged over the period from 1960 to 1974 (hereafter aggregate savings regression).

$$
\text { (1) }(\mathrm{I} / \mathrm{Y})_{\mathrm{i}}=\alpha+\beta(\mathrm{S} / \mathrm{Y})_{\mathrm{i}}+\varepsilon_{\mathrm{i}} \text {, }
$$

where $\mathrm{i}$ a country index, $(\mathrm{I} / \mathrm{Y})$ the domestic investment and $(\mathrm{S} / \mathrm{Y})$ the domestic saving rate, $\varepsilon$ a random error term with zero mean and constant variance. The beta coefficient measures the degree of capital mobility and is also called FeldsteinHorioka coefficient. According to Feldstein and Horioka financial markets are perfectly integrated into the world capital market, if the Feldstein-Horioka coefficient is insignificantly different from zero. In this case, domestic investments do not depend on domestic savings, since they are completely financed by the world wide pool of capital. Financial markets are conversely perfectly separated from the world capital market, if the Feldstein-Horioka coefficient is one. In this case, domestic investments are completely financed by domestic savings and a decline of the saving rate leads to a proportional decline of the domestic investment rate. Because Feldstein and Horioka got saving retention coefficients of 0.87 for gross and 0.93 for net domestic saving rates, they rejected the hypothesis of perfect capital mobility and concluded that "the evidence strongly contradicts the hypothesis of perfect capital mobility and indicates that most of incremental saving tends to remain in the country in which the saving is done" (Feldstein and Horioka, 1980, p. 321). This conclusion sparked off a great discussion about the validity of the Feldstein-Horioka criterion to measure the degree of financial market integration. The criticism mainly concentrated on the econometric techniques and the validity of the Feldstein-Horioka coefficient. Critics of the econometric techniques doubt that this coefficient measures the degree of international capital mobility because of the potential endogenity of real interest rates and savings rates (Feldstein and Horioka, 1980; Harberger, 1980 and Murphy, 1984). Critics of the validity of the FeldsteinHorioka coefficient argue that saving and investment rates are correlated even in case of perfectly integrated capital markets due to productivity and population effects, the intertemporal budget constraint and current account targeting policies of the government and the central bank (Artis and Bayoumi, 1990; Bayoumi, 1990; Coakley, Kulasi and Smith, 1995; Feldstein and Horioka, 1980; Sinn, 1992 and

For that reason, the financial markets in these countries are still not integrated into the Euro area according to the covered and uncovered interest rate parity. 
Summers, 1986). Taken this criticism into account and applying the FeldsteinHorioka test to other countries and periods however has not solved the FeldsteinHorioka paradox.

Buch (1999) was the first that used the Feldstein-Horioka approach to measure the degree of international capital mobility in central and eastern European countries. In her seminal paper on capital mobility and EU enlargement, she estimated the degree of financial integration for a panel of central and eastern European countries (Czech Republic, Estonia, Hungary, Poland and Slovenia). To compare the degree of integration with the countries that entered the EU last, she also measured the degree of capital mobility in Greece, Portugal and Spain. Buch concluded that the central and eastern European countries have reached almost the same degree of capital mobility like the three southern European countries and hence "that membership in the EU was unlikely to boost capital market integration to a significant degree and to trigger huge capital inflows" (Buch, 1999, p. 28).

This paper extends the approach by Buch in three ways. First, we include the Slovak Republic and eleven member states of the EMU in the sample to compare the degree of capital mobility of the CEEC-5 with that of the Euro area. The advantage of this approach over that of Buch is that we can analyse if the CEEC-5 still have to further integrate into the Euro area financial market to ensure an efficient monetary policy in an enlarged monetary union. Second, we increase the sample size by the period from 1998 to 2003. This allows us to test the hypothesis of Buch that EU membership will not likely increase degree of capital mobility according to the Feldstein-Horioka criterion. Third and last, we analyze the effect of current account targeting policies on the degree of financial integration. These policies might have biased the degree of financial integration of the central and eastern European countries in Buch, since many governments might have targeted the current account to prevent unsustainably large current account deficits.

\section{Saving Rates, Investment Rates and the Current Account}

The recession in the CEEC-5 at the beginning of the transformation period led to the decline of domestic investment and saving rates. Since mostly domestic saving rates dropped faster than domestic investment rates, the CEEC-5 faced a lack of domestic capital. This lack was financed by foreign capital, which increasingly flew into central and eastern European countries attracted by stable exchange rates and a great number of investment opportunities. Higher growth in the middle of the nineties further worsened the current account balance, because it often went hand in hand with higher investment rates. In most cases, these current account deficits could be financed by foreign capital. This capital was pulled out of these countries as these economies slipped into recession and investor confidence in the sustainability of the exchange rate regime diminished. In particular, countries which attracted high 
volumes of short-term portfolio investments in the past were vulnerable to capital outflows and had to devalue their currency following high pressure on the exchange rate target of the central bank. These currency crises often entailed severe financial crisis bringing the central and eastern European countries closer to recessions. The countries reacted differently on these shocks some adopting even harder exchange rate regimes and some letting the exchange rate float without interventions. Similar to all countries was the adoption of savings programs that were targeted on reducing the current account deficit.

Czech Republic (see Figure 1a in the Appendix): After the economic recovery in 1992 and 1993, investment and saving rates increased. However, since saving rates did not rise as fast as investment rates, domestic investment had to be financed by foreign capital. Due to the import of capital the Czech Republic recorded current account deficits in the following years which peaked in 1996 and 1997 with a deficit of more than 12 percent. As these deficits became unsustainable, speculative attacks were launched which led to a currency and banking crisis and forced the Czech central bank to abandon its exchange rate target in May 1997. Due to a savings program of the Czech government, higher private saving and lower investment rates following the recession of the Czech economy, the deficit dropped to 6 percent in 1998 and 1999. As the economy recovered, investment rates rose again and caused a temporary rise of the current account deficit to 8 percent in 2000, until it could be reduced to 5 percent in 2002 .

Hungary (see Figure 1b): The transition to a market-based economy started with a recession, which led to a decline of saving and investment rates. Since the saving rate dropped faster than investment rate, Hungary reported a current account deficit of nearly 10 percent in 1993 and 1994. This deficit dropped to almost 5 percent after the government launched a savings program in 1995 and 1996 that increased domestic savings without influencing the investment rate. Due to lower saving rates in the succeeding years and constantly high investment rates the deficit rose again to more than 8 percent in 2000 until it could be reduced to less than 6 percent in 2003 .

Poland (see Figure 1c): Due to a recession at the beginning of the transformation period saving and investment rates dropped significantly. Since the investment rate started to recover earlier than the savings rate, Poland recorded a current account deficit of more than 6 percent in 1993. This deficit dropped to less than 5 percent in 1995 due to higher domestic savings until it rose to almost 12 percent between 1997 and 1998 because of increasing domestic investments. Because of higher budget deficits between 1998 and 2001 aggregate savings decreased and foreign capital had to be imported to finance domestic investments. In 2000, the current account balance improved due to lower investment rates following a downturn of the Polish economy although aggregate savings decreased in this period as well. Due to constant saving 
and investment rates in the following years the current account stabilized at a deficit of less than 7 percent.

Slovak Republic (see Figure 1d): After a large current account deficit in 1993, a decline of the domestic investment rate and a rise of the saving rate led to an almost balanced current account. Since then the saving rate remained relatively stable, whereas the investment rate rose to 35 percent between 1996 and 1998 due to a rise of private and public investment. The current account deficit consequently rose to 13 percent in 1996 and peaked in 1998 with a deficit of 14 percent. These deficits were mainly financed by short-term foreign debt, which made the country vulnerable for speculative attacks from foreign investors. These attacks together with a rapid outflow of foreign capital led to a currency and current account crisis in 1998, which forced the Slovak central bank to give up its exchange rate target. After the crisis, the government launched a program to increase public savings. However, lower private saving rates more than compensated the public savings increase and aggregate savings further decreased. Only because of declining investment rates, the current account deficit could be reduced to nearly 7 percent in 2000. This deficit did not last for a long time. Due to an investment boom the current account deficit rose again to more than 13 percent until it could be lowered to 5 percent in 2003 as the boom came to an end.

Slovenia (see Figure 1e): The saving and investment rates remained relatively stable in relation to the other CEEC-5 countries. In 1991, Slovenia recorded a current account surplus, which however soon evolved into a current account deficit due to lower saving and higher investment rates. At the peak of the investment boom in 1999 and 2000, the deficit reached almost 8 percent. Due to an economic downturn investment rates declined and saving rates rose leading to a current account deficit of less than 4 percent in 2003.

\subsection{Saving and Investment Correlations in the CEEC-5}

The analysis of saving and investment patterns in the preceding section has shown that domestic investment rates did not depend on the domestic saving rate between 1993 and 2003 due to the import of foreign capital. For that reason, the financial markets of the CEEC-5 are neither perfectly integrated nor perfectly separated from the world capital market according to the Feldstein-Horioka criterion. To measure this degree of integration, correlation coefficients between domestic saving and investment rates are analyzed.

Since in a world of immobile capital domestic investments are completely financed by domestic savings, saving rates and investment rates have to be perfectly correlated. The correlation coefficient therefore has to be one in perfectly separated financial markets. On the contrary, if the domestic financial market is perfectly integrated into the world capital market, domestic investments are completely 
financed by the worldwide pool of capital and do not rely on domestic savings. The correlation coefficient is, for this reason, expected to be zero in perfectly integrated markets.

Table 1: Correlation Coefficients of Domestic Saving and Investment Rates

\begin{tabular}{|c|c|c|c|c|c|}
\hline & $\begin{array}{c}\text { Czech } \\
\text { Republic }\end{array}$ & Hungary & Poland & $\begin{array}{c}\text { Slovak } \\
\text { Republic }\end{array}$ & Slovenia \\
\hline $\begin{array}{l}\mathrm{S} / \mathrm{Y} \text { and } \\
\mathrm{I} / \mathrm{Y}\end{array}$ & -0.02 & 0.68 & 0.86 & 0.29 & 0.42 \\
\hline
\end{tabular}

Source: IFS (2005), own calculations

The correlation coefficients are presented in Table 1. According to these coefficients, the Czech financial market is almost perfectly integrated into the world capital market, since the correlation coefficient between the Czech saving and investment rate is zero. The financial markets of Poland, Hungary, the Slovak Republic and Slovenia are, on the contrary, still considerably separated from the world capital market indicated by a high correlation coefficient between saving and investment rates. In particular, the degree of financial market integration in Poland seems to be very low. The correlation coefficient between the Polish saving and investment rate is 0.86 indicating a high degree of financial market segmentation. However, we caution against taking these results seriously, since correlation does not imply causation. For that reason, we applied other techniques in the next section to measure the degree of financial integration econometrically.

\subsection{International Capital Mobility in the CEEC-5: The Feldstein- Horioka Approach}

In order to measure the degree of financial market integration in the CEEC-5 into the world capital market econometrically, we use the Feldstein-Horioka approach. Due to the lack of long time-series data the degree of financial integration is estimated only for the group and not for each country separately. This panel approach has the advantage that information from cross-sectional and time-series data is used to estimate the relationship between saving and investment rates. To compare the degree of capital mobility with the EMU countries, we also analyze the saving-investment correlations of Austria, Belgium, Finland, France, Germany, Greece, Ireland, Italy, the Netherlands, Portugal and Spain. ${ }^{2}$

\footnotetext{
${ }^{2}$ Luxemburg was excluded from the sample because it constitutes an outlier.
} 
Table 2: Domestic Saving and Investment Correlations

Equation (5) was estimated for annual data for the reform period (1989 to 2003) and for the entire period (1980 to 2003) as OLS panel regression with cross-section weights. The regression was estimated with autoregressive terms (AR) to remove serial correlation from the residuals and with country specific dummy variables to account for unobserved time invariant differences for each cross-sectional unit. (S/Y) is the aggregate saving retention coefficient. CZ, HU, PL, SLK and SL denote the individual country intercepts of the Czech Republic, Hungary, Poland, the Slovak Republic and Slovenia.

\begin{tabular}{|c|c|c|c|c|}
\hline & \multicolumn{2}{|c|}{ CEEC-5 } & \multicolumn{2}{|c|}{ Euro Area } \\
\hline & $1980-2003^{1}$ & 1989-2003 & $1980-2003^{2}$ & $1989-2003$ \\
\hline & \multicolumn{4}{|c|}{ Levels } \\
\hline $\mathrm{S} / \mathrm{Y}$ & $\begin{array}{c}0.41 * * * \\
(0.05)\end{array}$ & $\begin{array}{c}0.32 * * * \\
(0.06)\end{array}$ & $\begin{array}{c}0.55^{* * * *} \\
(0.05)\end{array}$ & $\begin{array}{c}0.47 * * * \\
(0.05)\end{array}$ \\
\hline $\mathrm{CZ}$ & $\begin{array}{c}0.21 * * * \\
(0.01)\end{array}$ & $\begin{array}{c}0.23 * * * \\
(0.01)\end{array}$ & & \\
\hline $\mathrm{HU}$ & $\begin{array}{c}0.16 * * * \\
(0.01)\end{array}$ & $\begin{array}{c}0.18 * * * \\
(0.01)\end{array}$ & & \\
\hline PL & $\begin{array}{c}0.15^{* * *} \\
(0.01)\end{array}$ & $\begin{array}{c}0.16 * * * \\
(0.01)\end{array}$ & & \\
\hline SLK & $\begin{array}{c}0.21 * * * \\
(0.02)\end{array}$ & $\begin{array}{c}0.23 * * * \\
(0.02)\end{array}$ & & \\
\hline SL & $\begin{array}{c}0.16^{* * *} \\
(0.01)\end{array}$ & $\begin{array}{c}0.18^{* * *} \\
(0.01\end{array}$ & & \\
\hline $\operatorname{AR}(1)$ & $\begin{array}{c}0.69 * * * \\
(0.10)\end{array}$ & $\begin{array}{c}0.81 * * * \\
(0.12)\end{array}$ & $\begin{array}{c}1.03 * * * \\
(0.05)\end{array}$ & $\begin{array}{c}1.12 * * * \\
(0.08)\end{array}$ \\
\hline $\operatorname{AR}(2)$ & $\begin{array}{c}-0.18^{* *} \\
(0.10)\end{array}$ & $\begin{array}{c}-0.31 * * * \\
(0.11)\end{array}$ & $\begin{array}{c}-0.25 * * * \\
(0.06)\end{array}$ & $\begin{array}{c}-0.41 * * * \\
(0.08)\end{array}$ \\
\hline $\mathrm{H}_{0}:(\mathrm{S} / \mathrm{Y})=1$ & $127.77 * * *$ & $105.24 * * *$ & $73.09 * * *$ & $98.41 * * *$ \\
\hline Obs. & 72 & 58 & 240 & 163 \\
\hline $\mathrm{R}^{2}$ & 0.80 & 0.82 & 0.88 & 0.88 \\
\hline DW & 1.83 & 2.08 & 1.77 & 1.85 \\
\hline \multirow[b]{2}{*}{$\mathrm{D}(\mathrm{S} / \mathrm{Y})$} & \multicolumn{4}{|c|}{ First Difference } \\
\hline & $\begin{array}{c}0.41 * * * \\
(0.05)\end{array}$ & $\begin{array}{c}0.36^{* * *} \\
(0.06)\end{array}$ & $\begin{array}{c}0.56^{* * *} \\
(0.05)\end{array}$ & $\begin{array}{c}0.52 * * * \\
(0.05)\end{array}$ \\
\hline $\mathrm{H}_{0}:(\mathrm{S} / \mathrm{Y})=1$ & $96.75 * * *$ & $85.60 * * *$ & $61.83 * * *$ & $65.47 * * *$ \\
\hline Obs. & 67 & 55 & 229 & 163 \\
\hline $\mathrm{R}^{2}$ & 0.41 & 0.44 & 0.52 & 0.44 \\
\hline DW & 2.00 & 2.21 & 1.70 & 1.90 \\
\hline
\end{tabular}

$1 * * *, * * *$ indicate significance at the 1,5 and 10 percent level, standard errors in parenthesis

${ }^{2}$ The intercept coefficients have not been reported but are available at request.

Source: IFS (2005), own calculation 
Equation (1) was estimated for annual data for the reform period (1989 to 2003) and for the entire period (1980 to 2003) (hereafter aggregate savings regression). In order to remove serial correlation from the residuals, autoregressive terms were used as additional regressors. To account for unobserved time invariant differences for each cross-sectional unit, the equation was furthermore estimated with country specific dummy variables. The regression results are presented in Table 2. The regressions confirm the conclusions we draw from the descriptive analysis of saving and investment rates, since the Feldstein-Horioka coefficient is 0.41 (with a standard error of 0.05$)$ over the total and $0.32(0.06)$ over the reform period indicating that the financial markets of the CEEC-5 are neither perfectly integrated into nor completely separated from the world capital market. A saving retention coefficient of 0.41 means that 41 percent of domestic investments are financed by domestic savings. A simple test to analyze if the coefficients in the total and reform period are significantly different is the Wald test. This test rejects the hypothesis that the coefficients are not significantly different. The degree of capital mobility thus seems to have significantly increased during the reform period. The same test rejects the hypothesis that the coefficients over the total and the reform period are not significantly different from unity. ${ }^{3}$

To find out if the CEEC-5 have already reached the same degree of integration as the EMU countries, we ran the Feldstein-Horioka regression for the countries in the Euro area as well. ${ }^{4}$ The regression results are presented in Table 2 as well. These results indicate that the CEEC-5 have already reached a higher degree of integration into the world capital market than the EMU countries in quantitative terms. The saving retention coefficient of the EMU countries for the entire period is 0.55 (with a standard error of 0.05) and that for the reform period $0.47(0.05)$. These estimates are close to the coefficients Buch (1999) estimated for southern Europe. Following Buch, Wald Tests were performed to test if the coefficients of the CEEC-5 and the EMU panel are identical. These tests do not reject the hypothesis that the coefficients over the total and the reform period are significantly different from each other. The same tests reveal that the coefficients over the entire and the reform period are significantly different from unity.

The higher degree of international capital mobility in the EMU in the reform period might be attributed to the removal of barriers that restricted the cross-border transfer of capital in the period before 1989. In the reform period, the EU finished the creation of the single market by the removal of capital and service controls within the EU. It might also explain the higher degree of capital mobility in the CEEC-5, since in 1998 the accession process to the EU started and was almost finished, during which the countries had to remove all existing controls on capital and

\footnotetext{
${ }^{3}$ These test and the following Wald Test results are available at request.

${ }^{4}$ Luxembourg was excluded from the sample.
} 
services to meet the accession criteria. That the CEEC-5 have already reached a higher degree of financial integration in the world capital market than the EMU countries indicate that the CEEC-5 used the accession process not only for removing barriers of capital toward the European, but also toward the world capital market, while the European countries seem to have more focused on the removal of frictions within EMU.

A problem with panel data regressions is that one of the time-series used might be nonstationary, since the regression of one nonstationary variable on another nonstationary variable leads to spurious results when no co-integration exists (Granger and Newbold, 1974). In this case, the results obtained from the panel regression above do not allow drawing any inference about the degree of financial integration. For that reason, we performed Augmented-Dickey Fuller (ADF) tests to find out if one of the saving and investment rate time-series is nonstationary (Dickey and Fuller, 1979). These tests indicate that the investment rate series of Poland and Slovenia are nonstationary and that of the Czech Republic, Hungary and the Slovak Republic are stationary. The same tests for the saving rate show that the Slovenian time-series are stationary, while those of the Czech Republic, Hungary, Poland and the Slovak Republic are nonstationary. ${ }^{5}$ Since saving and investment rates do not have the same degree of integration and the sample period is not sufficiently long, co-integration relationships between saving and investment rates could not be established. Following Buch (1999), we estimated equation (1) for this reason also in first differences. The regression results are presented at the bottom of Table 2 . As expected taking differences worsens the fit of the regression, since the $\mathrm{R}^{2}$ of the regression over the total and the reform period drops considerably. However, the Feldstein-Horioka coefficients of the total and the CEEC-5 sample regressions are still highly significant and insignificantly different from the coefficients of the panel regression in levels. ${ }^{6}$ For comparison purposes, we estimated equation (1) in first differences for the EMU countries as well. The regression results are also reported at the bottom of Table 2. The Feldstein-Horioka coefficients are slightly higher than those estimated in levels. Wald tests reject the hypotheses that the coefficients are insignificantly different from unity.

To summarize, panel data regressions over the entire period and the reform period in levels as well as first differences indicate that the degree of capital mobility in the CEEC-5 has increased to the level of the EMU countries due to the liberalization of capital flows. These results confirm the hypotheses of Buch (1999) that the central and eastern European countries have already reached the same degree of integration into the world capital market like the EMU countries and that the accession process would likely not further increase the degree of capital mobility, since the CEEC-5

\footnotetext{
${ }^{5}$ The ADF tests results are available at request.

${ }^{6}$ Wald Tests do not reject the null hypothesis that the coefficients are equal.
} 
already have a higher degree of capital mobility than the EMU countries. That might be explained with efforts of the CEEC-5 not only to reduce barriers toward the European, but also toward the world capital market.

Problematic is that the panel approach only measures the degree of capital mobility for a group of countries and not for each country separately. The degree of capital mobility might therefore have been biased by a small number of highly integrated countries even though the most countries in the panel are almost separated from the world capital market. The different correlation coefficients indicate that this effect might be responsible for the high degree of financial market integration in the CEEC-5. Another problem of the Feldstein-Horioka approach is that the estimates of the Feldstein-Horioka coefficients might have been biased by current account targeting policies of the government.

\section{The Feldstein-Horioka Approach and Current Account Targeting}

As noted in the second section, the approach by Feldstein and Horioka (1980) to measure the degree of financial integration is criticized, since it can indicate a low degree of financial integration even if financial markets are perfectly integrated due to the current account policy of the government. To make this relationship clear, we will start with the current account identity according to which the current account balance is equal to the sum of domestic saving and investment.

$$
\text { (2) } \mathrm{CA}=\mathrm{S}-\mathrm{I} \text {, }
$$

where $\mathrm{CA}$ is the current account balance, $\mathrm{S}$ domestic savings and I domestic investment. Since domestic savings can be decomposed into private and public savings, the identity above can be re-written as:

$$
\text { (3) } \mathrm{CA}=\mathrm{S}_{\mathrm{G}}+\mathrm{S}_{\mathrm{P}}-\mathrm{I} \text {, }
$$

where $I$ is private investment, $S_{P}$ private and $S_{G}$ public savings. Since the amount of public savings depends upon the revenues and expenditures of the government, equation (3) can be rearranged to:

$$
\text { (4) } \mathrm{CA}=(\mathrm{T}-\mathrm{G})+\left(\mathrm{S}_{\mathrm{P}}-\mathrm{I}\right) \text {, }
$$

where $\mathrm{T}$ is government revenues and $\mathrm{G}$ government expenditures. As illustrated by equation (4) the fiscal budget acts as adjustment variable, since the government can balance the current account by adjusting its budget to the difference between private savings and investments. If a country has higher investment than private savings rates, the government has to increase its savings by reducing government expenditures and/or by raising taxes to balance the current account. If domestic savings on the contrary exceed domestic investments, the government has to increase its debt to balance the current account. For that reason, the correlation of 
the spread between private savings and investments and the fiscal budget is expected to be negative in perfectly integrated capital markets, if the government has targeted the current account. ${ }^{7}$

The correlation between the fiscal budget and the spread between private savings and investment however might be negative, even if the government did not target the current account. Feldstein and Bachetta (1989) addressed this problem in their second paper on international capital mobility and argued that the negative correlation might have also been caused by the crowding out or crowding in of private investment in a world of immobile capital. In such a world, the domestic interest rate is completely determined by the domestic demand for and the supply of capital. An increase of government expenditures consequently causes the domestic interest rate to rise and to crowd out domestic investments, whereas a reduction of government expenditures causes the interest rate to decrease and to crowd in new investments. Thus even in a world of perfectly immobile capital the government budget and the difference between private saving and investment can be negatively correlated.

In order to find out whether the regression results of the panel regressions above are biased by fiscal policies, we have regressed the private and the public saving rate on the domestic investment rate for the period between 1980 and 2003 according to Feldstein and Bachetta (hereafter private savings regression). ${ }^{8}$

$$
\text { (5) }(\mathrm{I} / \mathrm{Y})_{\mathrm{it}}=\alpha_{\mathrm{i}}+\beta_{1}\left(\mathrm{~S}_{\mathrm{P}} / \mathrm{Y}\right)_{\mathrm{it}}+\beta_{2}\left(\mathrm{~S}_{\mathrm{G}} / \mathrm{Y}\right)_{\mathrm{it}}+\varepsilon_{\mathrm{it}} \text {, }
$$

where $i$ is a country and $t$ a time index. $\left(\mathrm{S}_{\mathrm{P}} / \mathrm{Y}\right)$ is the private saving rate, $\left(\mathrm{S}_{\mathrm{G}} / \mathrm{Y}\right)$ the public saving rate defined as the difference between public revenues and expenditures and $\varepsilon$ is a random error term with zero mean and constant variance. To allow for country specific variability, equation (5) was estimated with countryspecific dummy variables. Autoregressive terms were used to remove autocorrelation. Since some of the CEEC-5 countries targeted the saving and investment rate to balance the current account, we expect the public saving retention coefficient to be statistically significant and the private saving retention coefficient to be significantly lower in this regression than in the aggregate savings regression indicating a higher degree of capital mobility in the CEEC-5 than in the aggregate savings regression. The regression results are presented in Table 3.

7 Summers (1986) tested this relationship by regressing the difference between savings and investments on the government deficit to prove that the Feldstein and Horioka paradox can be explained by current account targeting. He interpreted his results as evidence of this policy and criticised the validity of the Feldstein-Horioka paradox.

${ }^{8}$ Artis and Bayoumi (1990) estimated monetary and fiscal reaction functions to find out if the current account was policy target of the government and the central bank. 
Table 3: Private and Public Saving and Investment Correlations

Equation (5) was estimated for annual data for the reform period (1989 to 2003) and for the entire period (1980 to 2003) as OLS panel regression with cross-section weights. The regression was estimated with autoregressive terms (AR) to remove serial correlation from the residuals and with country specific dummy variables to account for unobserved time invariant differences for each cross-sectional unit. $\left(\mathrm{S}_{\mathrm{P}} / \mathrm{Y}\right)$ and $\left(\mathrm{S}_{\mathrm{G}} / \mathrm{Y}\right)$ are the private and public saving retention coefficients. CZ, HU, PL, SLK and SL denote the individual country intercepts of the Czech Republic, Hungary, Poland, the Slovak Republic and Slovenia.

\begin{tabular}{|c|c|c|c|c|}
\hline & \multicolumn{2}{|c|}{ CEEC-5 } & \multicolumn{2}{|c|}{ Euro Area } \\
\hline & 1980 to $2003^{1}$ & 1989 to 2003 & 1980 to $2003^{2}$ & 1989 to 2003 \\
\hline & \multicolumn{4}{|c|}{ Levels } \\
\hline $\mathrm{S}_{\mathrm{P}} / \mathrm{Y}$ & $\begin{array}{c}0.35 * * * \\
(0.06)\end{array}$ & $\begin{array}{c}0.27 * * \\
(0.11)\end{array}$ & $\begin{array}{c}0.52 * * * \\
(0.05)\end{array}$ & $\begin{array}{c}0.44^{* * * *} \\
(0.05)\end{array}$ \\
\hline $\mathrm{S}_{\mathrm{G}} / \mathrm{Y}$ & $\begin{array}{c}0.45^{* * *} \\
(0.12)\end{array}$ & $\begin{array}{c}0.75^{* * *} \\
(0.12)\end{array}$ & $\begin{array}{c}0.59 * * * \\
(0.07)\end{array}$ & $\begin{array}{c}0.48 * * * \\
(0.06)\end{array}$ \\
\hline $\mathrm{CZ}$ & $\begin{array}{c}0.22 * * * \\
(0.01)\end{array}$ & $\begin{array}{c}0.24 * * * \\
(0.02)\end{array}$ & & \\
\hline $\mathrm{HU}$ & $\begin{array}{c}0.17 * * * \\
(0.01)\end{array}$ & $\begin{array}{c}0.21 * * * \\
(0.02)\end{array}$ & & \\
\hline PL & $\begin{array}{c}0.19 * * * \\
(0.01)\end{array}$ & $\begin{array}{c}0.20 * * * \\
(0.01)\end{array}$ & & \\
\hline SLK & $\begin{array}{c}0.21 * * * \\
(0.02)\end{array}$ & $\begin{array}{c}0.24 * * * \\
(0.03)\end{array}$ & & \\
\hline SL & $\begin{array}{c}0.17 * * * \\
(0.01)\end{array}$ & $\begin{array}{c}0.19 * * * \\
(0.02)\end{array}$ & & \\
\hline $\operatorname{AR}(1)$ & $\begin{array}{c}0.80 * * * \\
(0.14)\end{array}$ & $\begin{array}{c}0.86^{* * *} \\
(0.10)\end{array}$ & $\begin{array}{c}1.01^{* * * *} \\
(0.06)\end{array}$ & $\begin{array}{c}1.09 * * * \\
(0.09)\end{array}$ \\
\hline $\operatorname{AR}(2)$ & $\begin{array}{c}-0.41 * * * \\
(0.13)\end{array}$ & $\begin{array}{c}-0.53 * * * \\
(0.08)\end{array}$ & $\begin{array}{c}0.23 * * * \\
(0.06)\end{array}$ & $\begin{array}{c}-0.38 * * * \\
(0.08)\end{array}$ \\
\hline $\mathrm{H}_{0}:\left(\mathrm{S}_{\mathrm{P}} / \mathrm{Y}\right)=1$ & $105.79 * * *$ & $41.72 * * *$ & $70.66 * * *$ & $97.62 * * *$ \\
\hline Obs. & 53 & 44 & 209 & 132 \\
\hline $\mathrm{R}^{2}$ & 0.74 & 0.61 & 0.88 & 0.89 \\
\hline \multirow[t]{2}{*}{ DW } & 2.06 & 2.65 & 1.86 & 1.97 \\
\hline & \multicolumn{4}{|c|}{ First Difference } \\
\hline $\mathrm{D}\left(\mathrm{S}_{\mathrm{P}} / \mathrm{Y}\right)$ & $\begin{array}{l}0.23 * \\
(0.11)\end{array}$ & $\begin{array}{l}0.23^{*} \\
(0.13)\end{array}$ & $\begin{array}{c}0.55^{* * *} \\
(0.05)\end{array}$ & $\begin{array}{c}0.49 * * * \\
(0.06)\end{array}$ \\
\hline $\mathrm{D}\left(\mathrm{S}_{\mathrm{G}} / \mathrm{Y}\right)$ & $\begin{array}{l}0.40 * * \\
(0.15) \\
\end{array}$ & $\begin{array}{l}0.46^{* *} \\
(0.17) \\
\end{array}$ & $\begin{array}{c}0.64 * * * \\
(0.07) \\
\end{array}$ & $\begin{array}{c}0.57 * * * \\
(0.06) \\
\end{array}$ \\
\hline $\mathrm{H}_{0}: \mathrm{D}\left(\mathrm{S}_{\mathrm{P}} / \mathrm{Y}\right)=1$ & $41.25 * * *$ & $34.27 * * *$ & $56.26 * * *$ & $66.15 * * *$ \\
\hline Obs. & 59 & 48 & 198 & 132 \\
\hline $\mathrm{R}^{2}$ & 0.16 & 0.17 & 0.55 & 0.49 \\
\hline DW & 1.88 & 2.00 & 1.82 & 2.14 \\
\hline
\end{tabular}
parenthesis

2 Luxemburg was excluded from the regression due to a lack of data about public savings. Data about public savings for the period between 1999 and 2003 were not available for Austria, France, Germany, Greece and Portugal. The intercept coefficients of the EMU countries have not been reported but are available at request.

Source: IFS (2005), own calculations 
The regression model fits the data very well and all variables are as expected highly significant. The private saving retention coefficient over the total period is 0.35 (with a standard error of 0.06 ) and that of the public sector $0.45(0.12)$. For the reform period, the respective coefficient for the private sector is $0.27(0.11)$ and 0.75 $(0.12)$ for the public sector. Since the private savings retention coefficients are smaller than in the aggregate savings regressions, the degree of capital mobility seems to have been biased by fiscal policies. In particular, in the reform period the degree of financial market integration seems to have been significantly biased to lower capital mobility by government policies. The public saving retention coefficient almost adds up to unity with the private saving retention coefficient in this period indicating that the government has almost perfectly offset the gap between private savings and investments. Wald tests however do not reject the hypothesis that the private saving retention coefficients in the aggregate and private savings regression are identical. We hence conclude that contrary to our expectations the degree of financial market integration of the CEEC-5 does not seem to have been significantly biased fiscal policies of the government.

The results of the regression for the EMU countries also indicate that government policies have significantly targeted the current account, since the Feldstein-Horioka coefficients of the aggregate savings regressions are insignificantly different from the coefficients in the private savings regression. The respective coefficient for the private sector is 0.52 (with a standard error of 0.05 ) for the entire period and 0.44 (0.05) for the reform period. The respective public saving retention coefficients are $0.59(0.07)$ and $0.48(0.06)$. Wald tests reject the hypothesis that the coefficients of the private savings regression are significantly different from the aggregate savings regression and different from unity.

Following Buch (1999), we estimated equation (5) also in first differences to take account of the potential nonstationarity of the time-series. The regression results are presented at the bottom of Table 3. As for the aggregate savings regression taking differences worsened the fit of the regression. The Feldstein-Horioka coefficients of the entire and the reform period for the CEEC-5 and the EMU sample are however still (weakly) significant. Wald tests reject the hypothesis that the private and public saving retention coefficients of both panels and periods are significantly different from the coefficients in levels. ${ }^{9}$

To summarize, neither the private savings regression for the CEEC-5 nor for the EMU countries indicate that the degree of capital market integration has been significantly biased by government policies. The significance of the public saving retention coefficients however also indicates that the public saving rate is correlated to the investment rate. This however cannot be taken as evidence for or against

\footnotetext{
${ }^{9}$ Wald Tests do not reject the null hypothesis that the coefficients are equal.
} 
current account targeting policies of the government, since significant public saving retention coefficients are both consistent with a crowding out of private investments in case of low capital mobility and current account policies in case of high capital mobility. The private savings approach of the Feldstein-Horioka approach is hence inappropriate to find out if the government targeted the current account. We consequently have to apply other econometric techniques to analyse if the degree of financial market integration has been biased by current account targeting policies.

\subsection{Current Account Targeting and the Intertemporal Budget Constraint}

Since countries have to pay back foreign debt, they cannot infinitely borrow from abroad. This means that a country cannot permanently run current account deficits, if it is subject to an intertemporal budget constraint. For that reason, if the government successfully targets the current account to prevent unsustainable deficits, the current account time-series has to be stationary, since it cannot grow infinitely. This hypothesis can be tested by analyzing the unit root of the current account time-series. To do the test, we first generated the current account variable according to equation (2) as the difference between the domestic saving and investment rate. Then we performed ADF tests of these time-series to test for nonstationarity. If these tests indicate that the current account series have a unit root, governments did not target the current account. If the current account series are, on the other hand, stationary, the governments seem to have balanced the current account by adjusting their budget to the difference between private savings and investments to prevent unsustainable deficits between 1980 and 2003. Table 4 presents the test results.

Another method to estimate if the government targeted the current account is to analyze if the saving and investment rates are co-integrated. Since both series are normally nonstationary, the current account, which is a linear combination of these series, can only be stationary if saving and investment rates are co-integrated. Due to the lack of sufficiently long time-series, co-integration relationships between saving and investment rates however could not be established. This approach is hence inappropriate to analyze current account targeting policies of the government in central and eastern European countries.

The ADF tests come to different conclusions about the influence of the government on the current account. While the ADF tests of the Polish and the Hungarian current account indicate that the series are nonstationary, the tests of the Czech and the Slovakian current account balance point to stationarity. This means according to our interpretation that Poland and Hungary did not target the current account to prevent unsustainable current account deficits. The inversion of that argument however is not valid. The current account balance might be stationary even without government 
policies offsetting the difference between private savings and investments. The stationarity of the current account series in the Czech and Slovak Republic as well as Slovenia nonetheless indicates that the governments in these countries might have targeted the current account.

Table 4: ADF Tests of the Current Account Balance

\begin{tabular}{|l|c|c|c|c|c|}
\hline \multicolumn{3}{|c}{ Specification $^{1}$} & \multicolumn{4}{c}{ First Differences } & Degree of \\
Czech & & & & & \\
Republic & $0 \mathrm{C} 1$ & $-3.33^{* *}$ & $0 \mathrm{C} 1$ & $-2.84 *$ & $\mathrm{I}(0)$ \\
Hungary & $0 \mathrm{C} 0$ & -1.66 & $0 \mathrm{C} 0$ & $-4.82 * * *$ & $\mathrm{I}(1)$ \\
Poland & $0 \mathrm{C} 0$ & $-1,51$ & $0 \mathrm{C} 0$ & $-4.27 * * *$ & $\mathrm{I}(1)$ \\
Slovak & & & & & \\
Republic & $0 \mathrm{C} 1$ & $-3.36^{* *}$ & $0 \mathrm{C} 1$ & $-2.83^{*}$ & $\mathrm{I}(0)$ \\
Slovenia & $0 \mathrm{C} 0$ & $-2.73^{*}$ & $0 \mathrm{C} 0$ & $-7.86^{* * *}$ & $\mathrm{I}(0)$ \\
\hline
\end{tabular}

${ }^{1}$ Trend, constant, lag length

$2 * * *, * * *$ indicate significance at the 1,5 and 10 percent level

Sample period: 1993 to 2002 for the Czech Republic, 1980 to 2003 for Hungary and Poland, 1993 to 2003 for the Slovak Republic and 1991 to 2003 for Slovenia

Source: IFS (2005), own calculations

These results are in compliance with our observations in the third section, since both the Czech and the Slovak Republic launched saving programs after the currency crises in 1997 and 1998 to prevent further crises and recessions due to unsustainably high current account deficits. The savings program of the Hungarian government in 1997 conversely did not seem to have influenced the current account. That contradicts our conclusions in the third section about the effect of the savings program on aggregate savings and investments to balance the current account and indicates that the unit root test results are not robust. For that reason, we also ran Kwiatkowski, Phillips, Schmidt, and Shin (KPSS) Tests (Kwiatkowski et al., 1992). This test differs from the ADF test in that it tests the null hypothesis that the series is stationary, whereas the ADF test assumes that the series is nonstationary. The test results confirm the ADF test results for the Czech and the Slovak Republic as well as Slovenia. For Hungary and Poland the KPSS test however comes to different conclusions about the stationarity of the current account series. This might indicate that the unit root test results are not robust and hence have to be interpreted with caution. The short time period for which data about saving and investment rates are available might be a reason for this. It might also explain the conflicting result we got for the Hungarian current account balance. 


\section{Conclusions}

The integration of financial markets into the world capital market is important for economic growth in central and eastern European countries, since the access to foreign capital increases the number of investments and entails the transfer of technology and Know-how through foreign direct investment. Financial market integration is furthermore necessary for an efficient monetary policy in an enlarged monetary union, since different degrees of financial market integration cause different reactions on monetary impulses. The motivation of this study was to measure this degree of integration.

According to the analysis of saving and investments correlations the CEEC-5 are not perfectly integrated into the world capital market. They however could have increased the degree of financial integration during the transition period through the removal of capital and service controls. The analysis also showed that the accession to the EU and the EMU will likely not further increase the degree of financial integration of the CEEC-5 according to the Feldstein-Horioka criterion, since the latter have already reached and even exceeded the degree of integration as the member states of the euro area. These empirical findings are robust to current account targeting policies of the government although detailed analysis on the basis of unit root test revealed that in particular those CEEC- 5 countries targeted the current account that suffered from current account crises in the past. The study hence indicates that the accession to the EMU will likely not lead to asymmetric monetary policy impulses according to the Feldstein-Horioka criterion.

\section{References}

Artis M.J. and Tamin Bayoumi (1990), Global Capital Market Integration and the Current Account, in: M.P. Taylor (Ed.), Money and Financial Markets, Cambridge and Oxford, 297-307.

Bayoumi, Tamin (1990), Saving-Investment Correlations, in: International Monetary Fund Staff Papers 37, 360-387.

Buch, Claudia M. (1999), Capital Mobility and EU Enlargement, in: Kiel Working Paper No. 908.

Coakley, Jerry, Farida Kulasi and Ron Smith (1995), Current Account Solvency and the Feldstein-Horioka Puzzle, in: Working Paper Number 8/95R, Birbeck College, London.

Dickey, D.A. and W. A Fuller (1979), Distribution of the Estimators for Autoregressive Time-Series with a Unit Root, in: Journal of the American Statistical Association 74, 427-431.

Feldstein, Martin and Charles Horioka (1980), Domestic Saving and International Capital Flows, in: The Economic Journal 90, 314-329. 
Feldstein, Martin and Phillipe Bachetta (1989), National Saving and International Investment, in: Bernheim und Shoven (Ed.), National Saving and Economic Performance, University of Chicago Press, Chicago.

Granger, C.W.J. and P. Newbold (1974), Spurious Regressions in Econometrics, in: Journal of Econometrics 2, 111-120.

Harberger, Arnold C. (1980), Vignettes on the World Capital Market, in: The American Economic Review 70, 331-337.

Herrmann, S. and A. Jochem (2003), The international integration of money markets in the central and east European accession countries: deviations from covered interest parity, capital controls and inefficiencies in the financial sector, Economic Research Centre of the Deutsche Bundesbank Discussion Papers no. 07/03.

Herrmann, S. and A. Jochem (2003), The international integration of foreign exchange markets in the central and east European accession countries: speculative efficiency, transaction costs and exchange rate premiums, Economic Research Centre of the Deutsche Bundesbank Discussion Papers no. $08 / 03$.

International Financial Statistics CD ROM (2005), International Monetary Fund (Ed.), New York.

Kwiatkowski, Denis, Peter C. B. Phillips, Peter Schmidt \& Yongcheol Shin (1992), Testing the Null Hypothesis of Stationary against the Alternative of a Unit Root, Journal of Econometrics 54, 159-178.

Kwiatkowski, Denis, Peter C. B. Phillips, Peter Schmidt \& Yongcheol Shin (1992), Testing the Null Hypothesis of Stationary against the Alternative of a Unit Root, Journal of Econometrics 54, 159-178.

Murphy, Robert (1984), Capital Mobility and the Relationship between Saving and Investment Rates in the OECD Countries, in: Journal of International Money and Finance 3, 327-342.

Sinn, Stefan (1992), Saving-Investment Correlations and Capital Mobility: On the Evidence from Annual Data, in: The Economic Journal 102, 1162-1170.

Summers, Lawrence H. (1986), Tax Policy and International Competitiveness, in: Harvard Institute of Economic Research Discussion Paper 1256. 


\section{Appendix}

Figure 1: Saving Rates, Investment Rates and the Current Account

a) Czech Republic
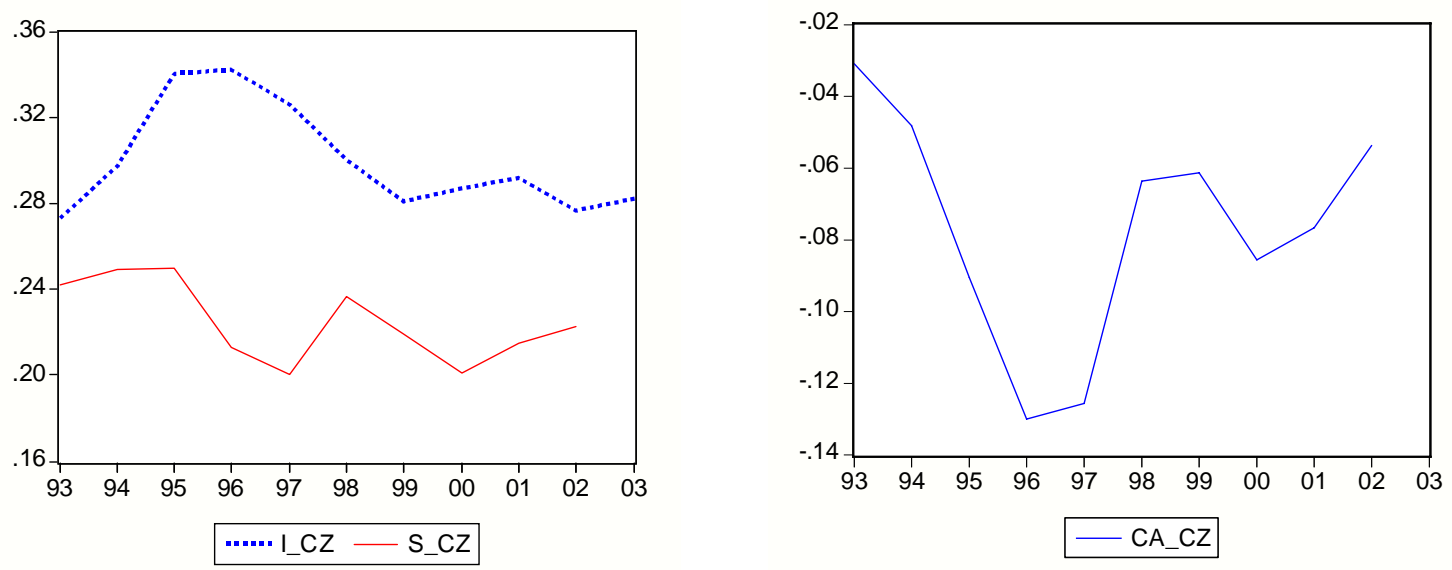

b) Hungary
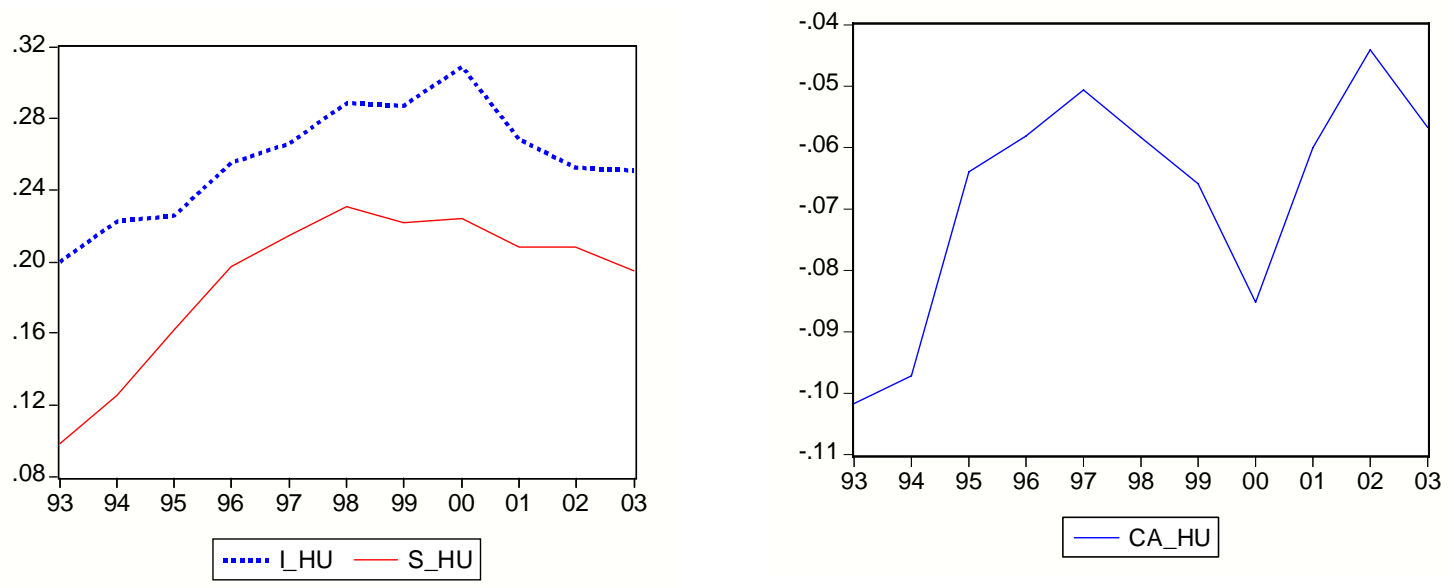

c) Poland
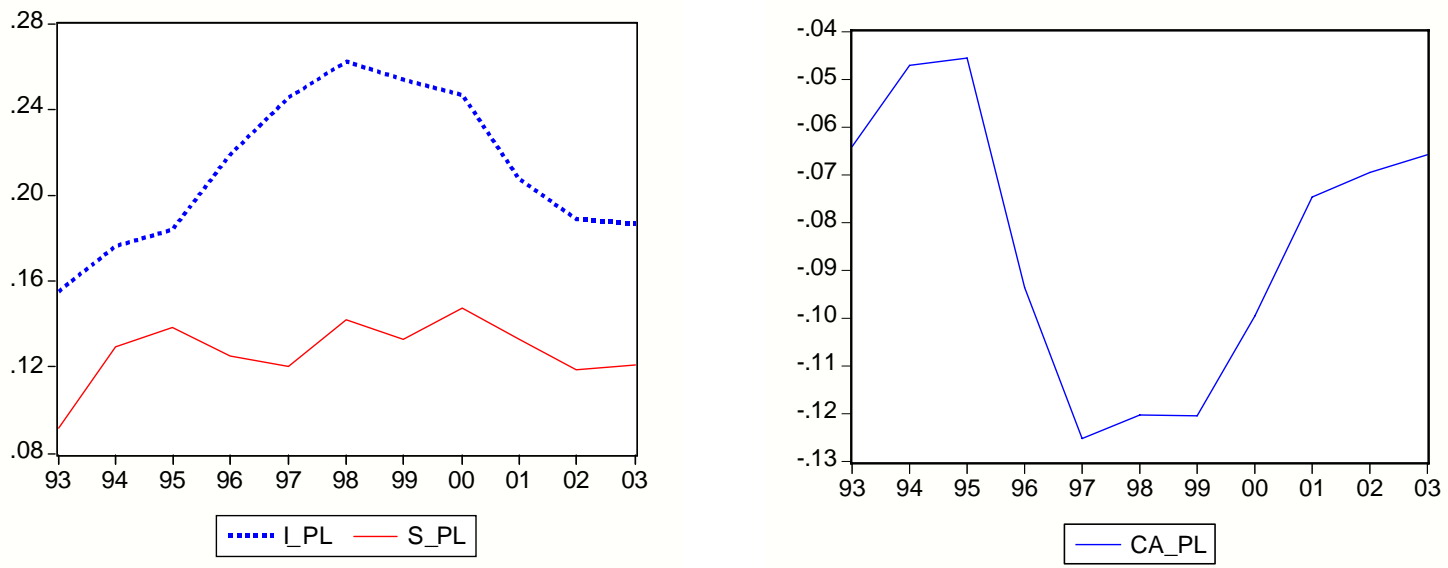
d) Slovak Republic
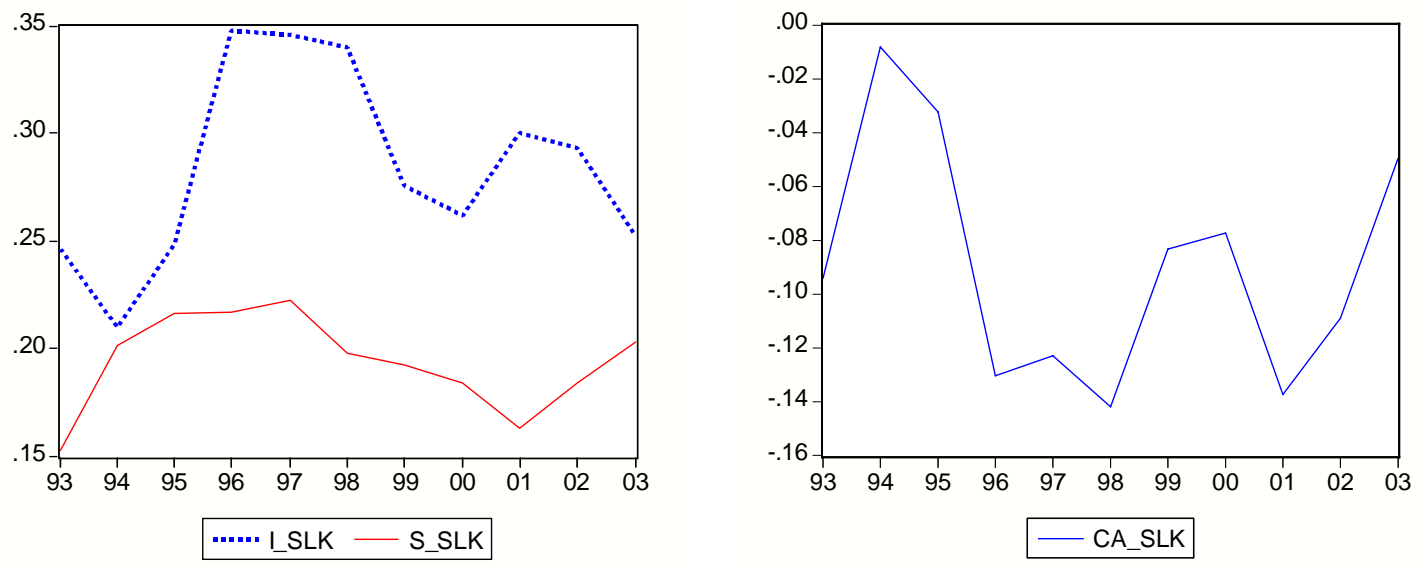

\section{e) Slovenia}
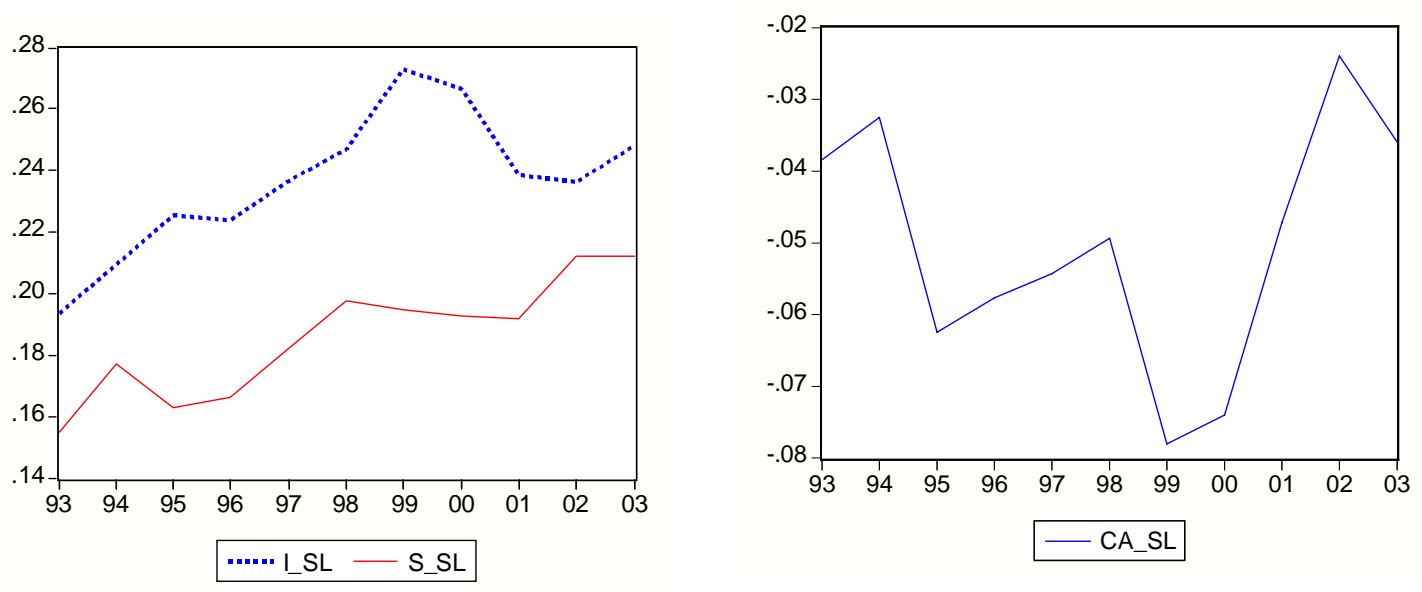